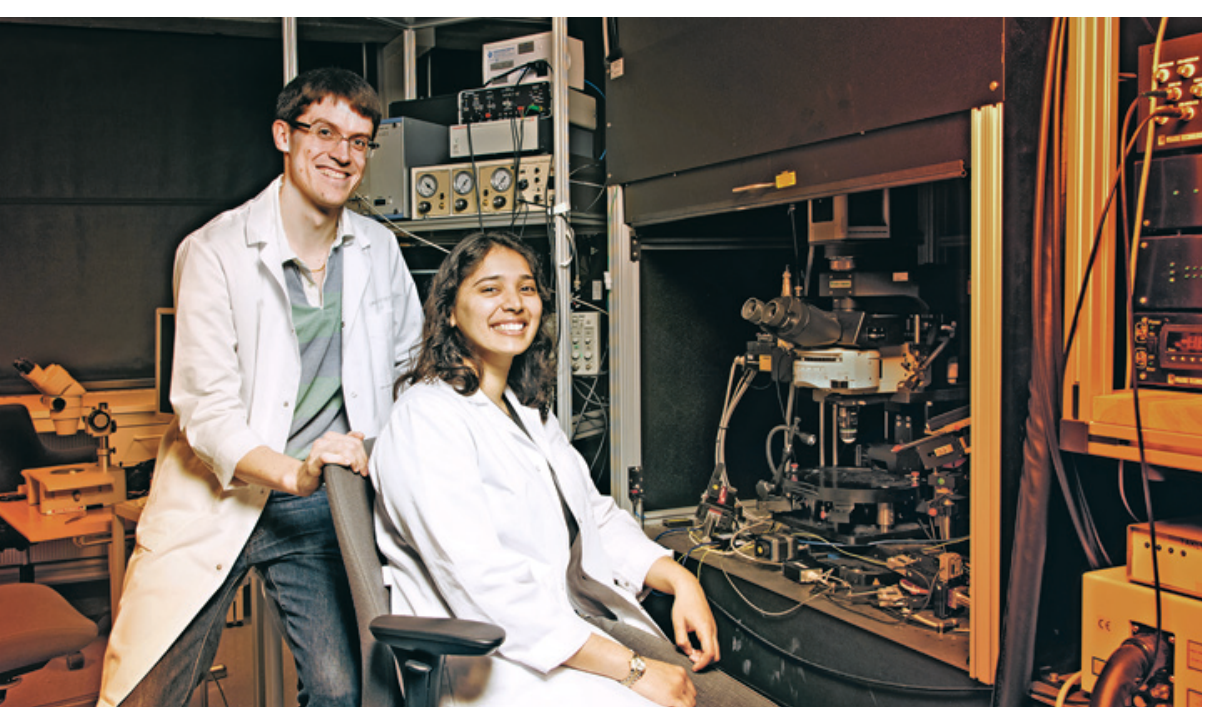

Vinita Rangroo Thrane og Alexander S. Thrane foran et tofotonmikroskop ved Lettensenteret, Universitetet i Oslo. Foto: John Hughes

\section{Ammoniakk hemmer kaliumtransport i gliaceller}

Ammoniakk er svært toksisk for hjernen. Norske forskere har funnet ut hvorfor.

Ammoniakk er nødvendig for danningen av aminosyrer, men er også et toksisk avfallsprodukt. Hvis nivået av ammoniakk i blodet blir for høyt, slik som ved leversvikt, kan det føre til kramper, koma og i verste fall død. Ammoniakk dannes også ved nedbrytningen av nevrotransmittoren glutamat og kan spille en rolle ved epilepsi hos barn.

En norsk forskergruppe har i samarbeid med amerikanske forskere vist at ammoniakk hemmer transporten av kalium i gliaceller i hjernen. Dette fører til opphopning av kalium i væsken rundt nervecellene og økt opptak av kalium og klorid i nervecellene. Dermed svekkes hemmende nerveimpulser (inhibisjon) i hjernebarken, og kramper kan oppstå. Forskerne har også vist at man kan redusere den skadelige effekten av ammoniakk ved hjelp av bumetanid, et diuretikum som blokkerer transportører av kalium og klorid. Studien er nylig publisert i tidsskriftet Nature Medicine (1).

- Tidligere studier har tydet på at den toksiske effekten av ammoniakk på hjernen skyldes at gliacellene sveller opp, sier forskerne Vinita Rangroo Thrane og Alexander S. Thrane ved Universitetet i Oslo, som begge er førsteforfattere av artikkelen.

- Dessverre har det ikke tidligere vært mulig å studere enkeltceller ikke-invasivt i hjernen på levende dyr. Bruk av nyere metoder, slik som tofotonmikroskopi har løst dette problemet, og våre funn med denne teknikken tyder altså på en annen mekanisme. Ytterligere dyreforsøk og kliniske studier er nødvendig for å avklare om bumetanid og andre kloridtransportørhemmere kan benyttes for å motvirke ammoniakkskade.

\section{Lettensenteret \\ for tofotonmikroskopi}

Studien er gjennomført ved Lettensenteret ved Universitetet i Oslo og ved University of Rochester i New York. Lettensenteret, som ledes av professor Erlend A. Nagelhus, har som hovedmål å studere signalering i hjernen. Sammen med rektor Ole Petter Ottersen startet Nagelhus i 2007 et langvarig samarbeid med professor Maiken Nedergaard ved University of Rochester. Nedergaard, som er sisteforfatter av den aktuelle artikkelen, har siden 1990-årene stått bak en rekke banebrytende studier om betydningen av gliaceller for normal hjernefunksjon og for sykdommer som hjerneslag, epilepsi og demens, blant annet med bruk av tofotonmikroskopi (2). Forskningsgruppen til professor Nagelhus har siden tatt i bruk denne teknikken ved sitt senter ved Universitet i Oslo, der det nå finnes tre slike mikroskoper.

\section{Kari Tveito \\ Tidsskriftet}

\section{Litteratur}

1. Rangroo Thrane V, Thrane AS, Wang F et al. Ammonia triggers neuronal disinhibition and seizures by impairing astrocyte potassium buffering. Nat Med 2013; 19: 1643-8.

2. Nedergaard M. Neuroscience. Garbage truck of the brain. Science 2013; 340: 1529-30.
Ordforklaringer

Tofotonmikroskopi: Bildeundersøkelsesteknikk som gjør det mulig å ta tredimensjonale bilder av enkeltceller i levende dyr. Raskt pulserende laserstråler benyttes for å sende lyspartikler (fotoner) inn i vevet.

Gliaceller: Hovedgruppen av ikke-nevronale celler i nervesystemet. De vanligste gliacellene i hjernen er stjerneliknende celler kalt astrocytter. Deres hovedfunksjon er å regulere transport av vann, ioner, glukose og signalsubstanser rundt nervecellene.

Kaliumkloridkotransportører: En gruppe livsviktige proteiner som transporterer kalium, klorid og i blant natrium over cellemembraner i ulike organer, bl.a. hjerne og nyrer. Flere diuretika virker ved å hemme disse transportørene.

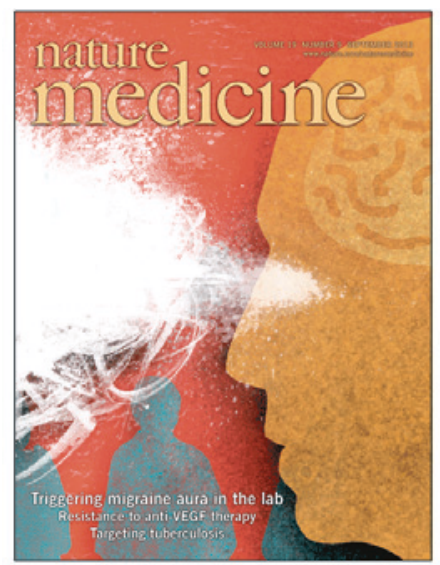

Artikkelen ble e-publisert 17. november 2013 i det prestisjetunge tidsskriftet Nature Medicine 